\title{
PENGARUH PARTISIPASI PENDIDIKAN TERHADAP TINGKAT KEMISKINAN DI PROVINSI JAWA TENGAH
}

\author{
Afifatul Hikma ${ }^{1}$, Sekar Ramadhani ${ }^{2}$, Nurizqi Amalia ${ }^{3}$ \\ 1,2,3 Universitas Gadjah Mada, Ekonomika Terapan/ Departemen Ekonomika dan Bisnis/ Sekolah Vokasi, \\ Yogyakarta, 55281 \\ Email : ${ }^{1}$ afifatulhikma40@ gmail.com, ${ }^{2}$ Sekarramadhani9@ gmail.com, ${ }^{3}$ nurizqiamaliatgs@gmail.com
}

\begin{abstract}
Abstrak
Penelitian ini adalah studi kasus pengaruh partisipasi sekolah (formal) terhadap tingkat kemiskinan di Provinsi Jawa Tengah. Dalam penelitian ini akan diketahui seberapa besar pengaruh angka partisipasi sekolah (APS) terhadap persentase penduduk miskin di Jawa Tengah. Metode yang digunakan dalam penelitian ini yaitu regresi linier berganda. Unit yang dianalisis adalah persentase angka partisipasi sekolah (APS), angka partisipasi kasar (APK), angka partisipasi murni (APM) dari tahun 2008 sampai tahun 2017. Sumber data yang dianalisis merupakan data sekunder yang dipublikasikan oleh Biro Pusat Statistik (BPS) Provinsi Jawa Tengah. Dalam penelitian ini dapat diketahui bahwa dari ke 3 data yaitu angka partisipasi sekolah, angka partisipasi murni, dan angka partisipasi kasar, yang paling besar pegaruhnya terhadap persentase jumlah penduduk miskin di Jawa Tengah adalah angka partisipasi sekolah yaitu sekitar $1,216 \%$
\end{abstract}

Kata Kunci : Kemiskinan, pendidikan, partisipasisekolah

\begin{abstract}
This research is a case study about the effect of education participation on the level of poverty in Central Java Province. In this research, it will be known how much influence the education participation has on the percentage of poor people in Central Java. The method used in this study is regression - multiple linear. The units analyzed were the percentage of school enrollment rate (SER), gross participation rate (GER), net enrollment rate (NER) from 2008 until 2017. The data sources analyzed were secondary data published by the Central Bureauof Statistics (BPS) of Central Java. In this study, it can be seen that from the 3 data on education participation, thare are school enrollment rates, pure enrollment rates, and gross enrollment rates, the greatest impact on the percentage of poor people in Central Java is the school enrollment rate, which affects around $1.216 \%$
\end{abstract}

Keyword : Poor, education, education participation 


\section{PENDAHULUAN}

Kemiskinan menjadi salah satu persoalan yang menjadi perhatian pemerintah di negara manapun. Kemiskinan adalah ketidakmampuan untuk memenuhi standar hidup minimum. Kemiskinan menjadi gambaran kehidupan di berbagi negara berkembang, salah satunya Negara Indonesia. Kemiskinan menjadi salah satu permasalahan yang belum mampu dihadapi dan diselesaikan secara tuntas oleh pemerintah, baik pemerintah pusat maupun daerah. Kondisi kemiskinan di Negara Indonesia diperparah dengan adanya krisis ekonomi pada tahun 1998. Dalam kondisi tersebut jumlah penduduk miskin bertambah sangat pesat. Peningkatan jumlah penduduk miskin dari tahun

1996-1998 menunjukkan presentase sebesar $20,30 \%$.

Jumlah penduduk miskin di Indonesia setiap tahunnya mengalami perkembangan yang fluktuatif tetapi cenderung mengalami penurunan. Hal tersebut, disebabkan

adanya usaha pemerintah dalam penanggulangan masalah kemiskinan.

Penanggulangan kemiskinan bahkan menjadi salah satu program prioritas bagi pemerintah daerah. Presentase jumlah penduduk miskin di Indonesia khususnya di pulau Jawa lebih dari 50\%, Provinsi Jawa Tengah menempati tingkat kemiskinan absolut tertinggi se-Jawa. Total penduduk miskin di Jawa Tengah dari 3 tahun terakhir

\section{RUMUSAN MASALAH}

1. Bagaimana pengaruh angka partisipasi sekolah (APS) terhadap tingkat kemiskinan di provinsi Jawa Tengah?

2. Bagaimana pengaruh angka partisipasi murni (APM) terhadap tingkat kemiskinan di provinsi Jawa Tengah? mengalami penurunan. Dari tahun 2016 berjumlah 4.506.89 turun menjadi 4.450,72.

Masalah kemiskinan dipengaruhi oleh beberapa faktor, salah satunya partisipasi dan tingkat pendidikan. Penyelenggaraan pendidikan di Indonesia khususnya pendidikan formal yaitu jenjang dasar, menengah dan tinggi. Jenjang pendidikan adalah tahapan pendidikan yang ditentukan berdasarkan tingkat perkembangan peserta didik, tujuan pendidikan yang akan dicapai, dan kemampuan peserta didik yang akan dikembangkan ( Rohman, 2009). Pembiayaan pendidikan semakin ditingkatkan oleh pemerintah oleh provinsi pemerintah Jawa Tengah. Peningkatan fasilitas pendidikan dan pemberian bantuan pendidikan oleh pemerintah diharapkan mampu mengurangi jumlah penduduk miskin dengan menjadikan generasi penerus bangsa yang terdidik yaitu dengan meningkatkan tingkat partisipasi sekolah. Sehingga tingkat pendidikan yang tinggi akan mengurangi tingkat pengaangguran yang nantinya akan menurunkan jumlah kemiskinan di Jawa Tengah. Namun kenyataannya tingkat pendidikan penduduk miskin rata-rata masih rendah. Penduduk miskin yang menamatkan tingkat pendidikan tinggi sangatlah sedikit. Penelitian ini bertujuan menganalisis pengaruh presentase tingkat partisipasi pendidikan terhadap tingkat kemiskinan.

3. Bagaimana pengaruh angka partisipasi kasar (APK ) terhadap tingkat kemiskinan di provinsi Jawa Tengah?

4. Bagaimana pengaruh partisipasi pendidikan terhadap tingkat kemiskinan di Provinsi Jawa Tengah 


\section{TINJAUAN PUSTAKA}

\section{Pendidikan}

Kata pendidikan itu sendiri berasal dari bahasa Latin yaitu ducare, berarti "menuntun, mengarahkan, atau memimpin" dan awalan $e$, berarti "keluar", memunculkan atau menggali potensi dari anak didik tersebut. Menurut Ki Hajar Dewantara pendidikan adalah daya upaya untuk memajukan budi pekerti, pikiran, serta jasmani anak, agar dapat memajukan kesempurnaan hidup yaitu hidup dan menghidupkan anak yang selaras dengan alam dan masyarakatnya. Pendidikan ini merupakan modal yang paling besar bagi bangsa dan negara. Dalam Undang-Undang dasar 1945 pasal 27 menyatakan bahwa pendidikan sebagai penyiapan warga negara yang baik, yakni warga negara yang tau hak dan kewajiban.

Pada hakekatnya, pendidikan itu berlangsung sepanjang masa atau seumur hidup manusia .Oleh karena itu, secara hakiki, pembangunan pendidikan merupakan bagian yang tidak terpisahkan dalamupaya pembangunan manusia. Upaya-upaya pembangunan di bidang pendidikan, pada dasarnya diarahkan untuk mewujudkan kesejahteraan manusia itu sendiri.

\section{Partisipasi pendidikan}

a. Angka Partisipasi Kasar

Indikator lain yang sering digunakan untuk mengukur pencapaian kesetaraan gender pada bidang pendidikan adalah Angka Partisipasi Kasar ( APK ). Menurut BPS (Badan Pusat Statistik ) mengatakan bahwa proporsi anak sekolah pada suatu jenjang tertentu terhadap penduduk pada kelompok usia tertentu. Sejak tahun 2007 Pendidikan Non Formal (Paket a, Paket B, Paket C ) turut memperhitungkan.

APK ini digunakan untuk menunjukkan tingkat partisipasi penduduk secara umum pada suatu tingkat pendidikan. Jadi, APK tinggi menunjukkan tingginya tingkat partisipasi sekolah, tanpa memperhatikan ketepatan usia sekolah pada jenjang pendidikannya. Jika nilai APK mendekati atau lebih dari 100 persen maka menunjukkan bahwa ada penduduk yang sekolah belum mencukupi umur dan atau melebihi umur yang seharusnya. Hal ini juga dapat menunjukkan bahwa wilayah tersebut mampu menampung penduduk usia sekolah lebih dari target yang sesungguhnya.

\section{b. Angka Partisipasi Murni}

Indikator Angka Partisipasi Murni ini merupakan indikator yang lebih baik dibandingkan dengan APK. Karena APM ini digunakan untuk mengukur indikator presentasi angka partisipasi sekolah dengan kelompok anak sekolah pada waktu dan usia yang sesuai atau tepat waktu, sedangkan APK (Angka Partisipasi Kasar) ini digunakan untuk mengukur presentasi anak yang sekolah dengan usia, waktu yang kurang atau lebih dari yang seharusnya.

Menurut BPS (Badan Pusat Statistik), APM (Angka Partisipasi Murni) adalah proporsi penduduk pada kelompok umur jenjang pendidikan tertentu yang masih bersekolah terhadap penduduk pada keolompok umur tersebut. APM ini menunjukkan seberapa banyak penduduk usia sekolah yang sudah dapat memanfaatkan fasilitas pendidikan sesuai pada jenjang pendidikannya. Jika APM = 100 , berarti seluruh anak usia sekolah dapat bersekolah tepat wkatu.

\section{Kemiskinan}

Menurut BAPPENAS kemiskinan adalah situasi serba kekurangan karena keadaan yang tidak dapat dihindari oleh seseorang dengan kekuatan yang dimilikinya 
Untuk mengukur kemiskinan, BPS menggunakan konsep kemampuan memenuhi kebutuhan dasar (basic needs approach). Dengan pendekatan ini,

kemiskinan dipandang sebagai ketidakmampuan dari sisi ekonomi untuk memenuhikebutuhan dasar makanandan bukan makanan yang diukur dari sisi pengeluaran. Jadi penduduk miskin adalah penduduk yang memiliki rata-rata pengeluaran perkapita perbulan dibawah garis kemiskinan.

\section{HASIL DAN PEMBAHASAN}

\section{Deskripsi data}

1. Jumlah Penduduk Miskin di Provinsi Jawa Tengah

\section{Jumlah Penduduk}

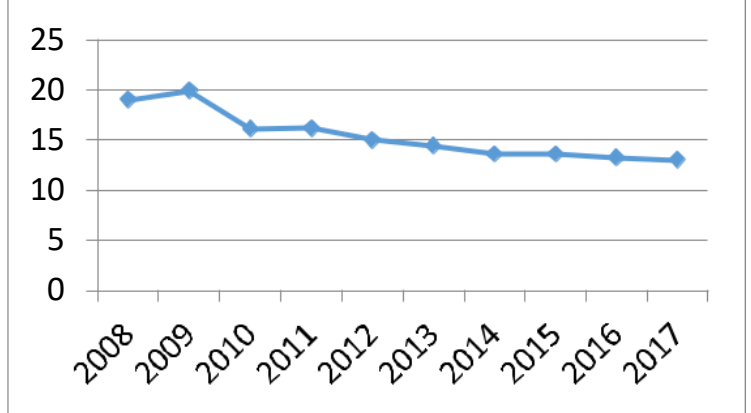

gambar 1 persentase jumlah penduduk miskin di Jawa Tengah

Pada gambar diatas menjelaskan adanya penurunan jumlah penduduk miskin di Provinsi Jawa Tengah selama 10 periode dari tahun 2008 sampai dengan tahun 2017.

2. Angka Partisipasi Sekolah

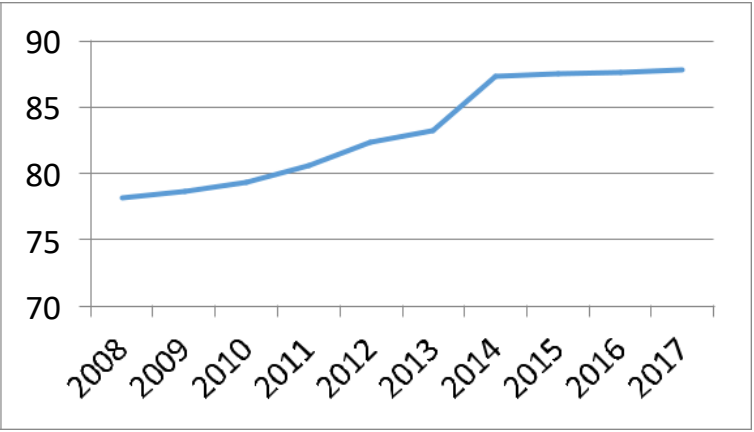

gambar 2 Angka Partisipasi Sekolah (APS) di Provinsi Jawa Tengah

Pada gambar diatas menjelaskan tentang persentase partisipasi sekolah di Provinsi Jawa Tengah. Dari data tersebut terjadi kenaikan paling besar pada tahun 2013 2014. Peningkatan tersebut karena adanya peningkatan sosialisasi sekolah dalam menyerap anak-anak yang berada di usia sekolah untuk bersekolah. Jumlah sekolah di Provinsi Jawa Tengah baik negeri maupun swasta sudah tersedia cukup banyak sehingga masyarakat bisa dengan mudah mengakses pendidikan.

3. Angka Partisipasi Murni

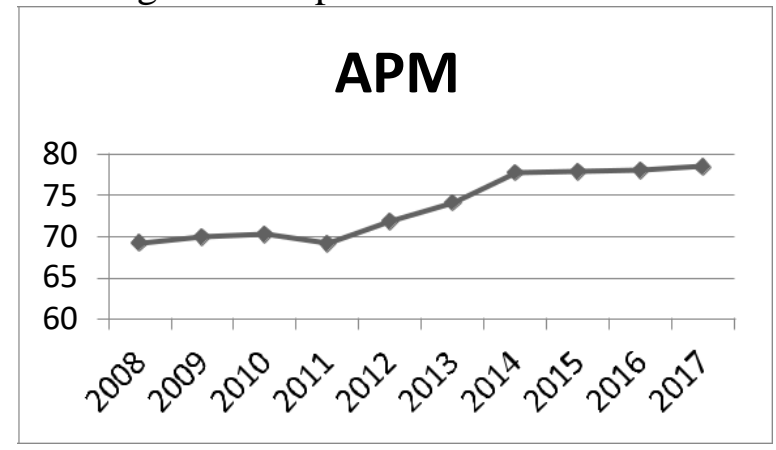

gambar 3 Persentase Angka Partisipasi Murni di provinsi Jawa Tengah

pada gambar 3 yang menjelaskan tentang persentase angka partisipasi murni terlihat bahwa sebagian besar perubahannya mengalami kenaikan, hanya saja pada tahun 2011 mengalami penurunan. Hasilnya sudah cukup baik karena data tersebut bisa menunjukan adanya peningkatan kesadaran masyarakat akan pentingnya wajib di Provinsi Jawa Tengah.

4. Angka Partisipasi Kasar 


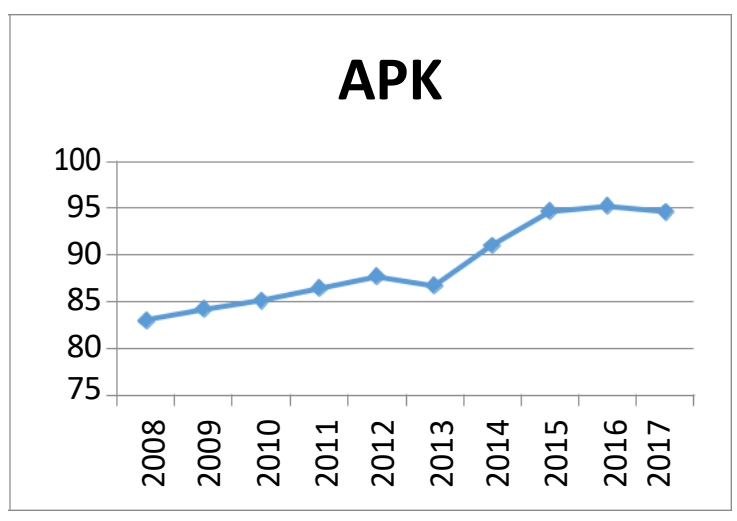

gambar 4 Angka Prtisipasi Kasar (APK) di Provinsi Jawa Tengah

pada gambar diatas menjelaskan tentang persentase angka partisipasi kasar di Provinsi Jawa Tengah pada tahun 2008 sampai dengan tahun 2017. Selama 10 periode telat terjadi 2 kali penurunan yang terjadi pada tahun 2013 dan tahun 2017. Penurunan tersebut disebabkan karena

kurang meratanya Program Kartu Indonesia Pintar (KIP) terhadap masyarakat di Provinsi Jawa Tengah, sehingga masih ada sebagian penduduk kurang mampu yang tidak terdaftar sebagai penerima KIP. Hal itu berakibat terputusnya pedidikan pelajar karena masalah biaya yang menjadikan angka partisipasi kasar menjadi turun.
Pengaruh Angka Prtisipasi Pendidikan terhadap Persentase Jumlah Penduduk Miskin di Provinsi Jawa Tengah

Descriptive Statistics

\begin{tabular}{|c|c|c|c|}
\hline & Mean & $\begin{array}{l}\text { Std. } \\
\text { Deviatio } \\
n\end{array}$ & $\mathrm{~N}$ \\
\hline $\begin{array}{l}\text { pend_jateng } \\
\text { miskin }\end{array}$ & $\begin{array}{r}15,40 \\
50\end{array}$ & 2,40579 & 10 \\
\hline APS & $\begin{array}{r}83,28 \\
00\end{array}$ & 4,00684 & 10 \\
\hline APM & $\begin{array}{r}73,65 \\
40\end{array}$ & 4,01840 & 10 \\
\hline APK & $\begin{array}{r}88,88 \\
60\end{array}$ & 4,63241 & 10 \\
\hline
\end{tabular}

Diperoleh penjelasan bahwa rata-rata dari data yang dianalisis dalam penelitian ini yaitu :

Angka Partisipasi Sekolah Provinsi Jawa Tengah $2008-2017=83,28 \%$

Angka Partisipasi Murni Provinsi Jawa Tengah $2008-2017=73,65 \%$

Angka Partisipasi Kasar Provinsi Jawa Tengah $2008-2017=88,89 \%$

\begin{tabular}{|c|c|c|c|c|}
\hline \multicolumn{5}{|c|}{ Model Summary } \\
\hline $\begin{array}{l}\text { Mode } \\
1\end{array}$ & $\mathrm{R}$ & R Square & $\begin{array}{c}\text { Adjusted R } \\
\text { Square }\end{array}$ & $\begin{array}{l}\text { Std. Error of } \\
\text { the Estimate }\end{array}$ \\
\hline 1 &, $925^{\mathrm{a}}$ & ,856 & ,784 & 1,11799 \\
\hline
\end{tabular}

a. Predictors: (Constant), APK, APM, APS

Dependent Variable:

Coefficients $^{\mathrm{a}}$

\begin{tabular}{|cl|l|l|l|l|l|}
\hline \multicolumn{2}{|l|}{ Model } & \multicolumn{2}{|l|}{$\begin{array}{l}\text { Unstandardized } \\
\text { Coefficients }\end{array}$} & $\begin{array}{l}\text { Standardized } \\
\text { Coefficients }\end{array}$ & & \multirow{2}{*}{ Sig. } \\
\cline { 3 - 5 } & & B & Std. Error & Beta & & \\
\hline \multirow{4}{*}{1} & (Constant) & 65,361 & 8,677 & & 7,533 &, 000 \\
& APS & $-1,216$ &, 590 & $-2,026$ & $-2,060$ &, 085 \\
& APM &, 500 &, 448 &, 835 & 1,117 &, 307 \\
& APK &, 163 &, 296 &, 314 &, 551 &, 601 \\
\hline
\end{tabular}

a. Dependent Variable: pend_jateng_miskin 
Correlations

\begin{tabular}{|c|c|c|c|c|c|}
\hline & & $\begin{array}{c}\text { pend_jateng } \\
\text { _miskin }\end{array}$ & APS & APM & APK \\
\hline & pend_jateng_mis & & & & \\
\hline Pearson & kin & 1,000 &,- 907 &,- 853 &,- 855 \\
\hline Correlatio & APS &,- 907 & 1,000 & ,978 & ,962 \\
\hline $\mathrm{n}$ & APM &,- 853 & ,978 & 1,000 & ,933 \\
\hline & APK &,- 855 & 962 & 933 & 1,000 \\
\hline & $\begin{array}{l}\text { pend_jateng_mis } \\
\text { kin }\end{array}$ & &, 000 & ,001 & ,001 \\
\hline 1 & APS &, 000 & & .000 & .000 \\
\hline (1-talled) & APM & ,001 &, 000 & &, 000 \\
\hline & APK & , 001 &, 000 & ,000 & \\
\hline & $\begin{array}{l}\text { pend_jateng_mis } \\
\text { kin }\end{array}$ & 10 & 10 & 10 & 10 \\
\hline $\mathrm{N}$ & APS & 10 & 10 & 10 & 10 \\
\hline & APM & 10 & 10 & 10 & 10 \\
\hline & APK & 10 & 10 & 10 & 10 \\
\hline
\end{tabular}

b. pend_jateng_miskin Berdasarka data

diatas :

Partisipasi pendidikan mempengaruhi persentase jumlah penduduk miskin di Provinsi Jawa Tengah sebanyak 0,784 atau sebesar 78,4\%, sisanya sebesar 21,6 dipengaruhi oleh variabel lain diluar model.

$\alpha=65,361$

$\beta$ APS $=-1,216$

$\beta \mathrm{APM}=0,500$

$\beta \mathrm{APK}=0,163$

Kemiskinan $=65,361-1,216$ APS + 0,500 APM + 0,163 APK + e

Interpretasi :

Konstanta merupakan nilai variabel dependent ketika independenya sama dengan nol. Artinya ketika perusahan tidak mengeluarkan biaya untuk melakukan promosi maka penjualan tetap dilakukan sebesar $\mathbf{6 5 , 3 6 1}$
- Angka Partisipasi Sekolah merupakan setiap kenaikan $1 \%$ akan menurunkan 1,216 \% kemiskinan di Provinsi Jawa Tengah.

- Angka Partisipasi murni merupakan setiap kenaikan $1 \%$ akan menurunkan $0,5 \%$ kemiskinan di Provinsi Jawa Tengah.

- Angka Partisipasi kasar merupakan setiap kenaikan $1 \%$ akan menurunkan $\quad 0,163 \quad \%$ kemiskinan di Provinsi Jawa Tengah 


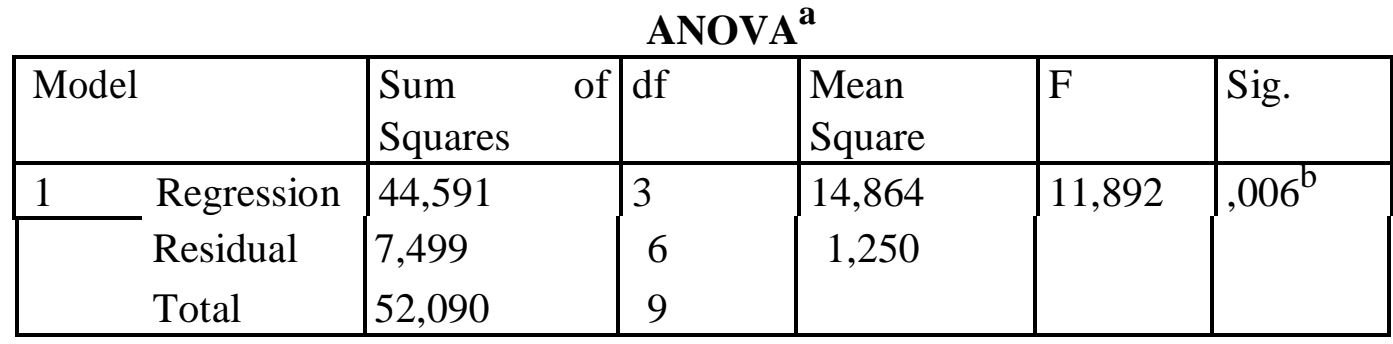

menerima bantuantersebut. Sehingga,

a. Dependent Variable: pend_jateng_miskin Predictors: (Constant), APK, APM, APS signifikansi $=0,006$

$\alpha=0,05$ dapat membantu dan berpengaruh positif.

$0,006<0,05$

\section{UCAPAN TERIMA KASIH}

Ucapan terima kasih kami tujukan kepada dosen pembimbung e-Journal,

Sehingga, model regresi dapat digunakan sebagai alat prediksi kemiskinan.

\section{KESIMPULAN DAN SARAN}

Kesimpulan

Dalam penelitian kasus ini dapat disimpulkan bahwa partisipasi pendidikan berpengaruh terhadap tingkat kemiskinan di Jawa Tengah. Berdasarkan data yang diambil dari tahun 2008 sampai dengan tahu 2017, pengaruh partisipasi pedidikan terhadap kemiskinan di Jawa Tengah sebesar $78,4 \%$.

\section{Saran}

Program pemerintah sudah cukup bagus dalam menyukseskan program-program di bidag pendidikan, baik itu KIP ataupun bantuan lain dari pemerintah. Untuk lebih baiknya yaitu meningkatkan pemerataan terhadap penerima program-program tersebut sehigga program tersebut bisa berada Nurizqi Amalia, S.Pd., M.Sc. dan teman-teman yang telah melancarkan pembuatan e-Journal ini. Kemudian e-Journal ini kami maksudkan untuk memperluas pengetahuan pembaca pada umunya dan pengetahuan penulis khususnya. Banyak kekurangan yang terdapat dalam penulisan e-Journal ini, oleh sebab itu demi penyempurnaan e-Journal ini, saran dan kritik saran dari pembaca sangat kami butuhkan.

\section{DAFTAR PUSTAKA}

\section{JURNAL-JURNAL}

Dini Amaliah, 2015, Pengaruh Partisipasi Pendidikan Terhadap Persentase Penduduk Miskin, Faktor Jurnal Ilmiah Kependidikan, Vol. 2 No. 3, hal 231-239

Meirinaldi, 2016, Peran Sektor Finansial dalam Menggerakkan Pertumbuhan, Ekspor dan Impor di Indonesia pada Dasawarsa 1982-2010, Jurnal Ekonomi, Vol. 18 Nomor 2, Juni 2016 
ditangan yang memang seharusnya 